\title{
PENGARUH GUNCANGAN KEBIJAKAN MONETER DAN VARIABEL MAKRO TERHADAP DANA PIHAK KETIGA (DPK) BANK SYAIRAH DI INDONESIA 1 )
}

\author{
Mohammad Abdul Adim \\ Mahasiswa Program Studi S1 Ekonomi Islam-Fakultas Ekonomi dan Bisnis-Universitas Airlangga \\ Email : mohammad.abdul-12@feb.unair.ac.id
}

Raditya Sukmana

Departemen Ekonomi Syariah-Fakultas Ekonomi dan Bisnis-Universitas Airlangga

Email : raditya-s@feb.unair.ac.id

\begin{abstract}
:
The purpose of this research is to find out the effect of monetary policy shocks and macro variables towards Islamic banks deposits. The method that used in this researc his quantitative method and also using secondary data which obtained from financial reports and other reports started from 2005 until the end of 2015. Analysis technique used is Johansen Cointegration and Vector Autoregressive (VAR). The result are monetary policy shocks have affect significant on deposits Islamic banks in long run and short run. Furthermore, variables macroeckonomic like GDP and CPI have effect significant on deposits in Islamic banks. interestingly, the money supply in the long run have significant effect on Islaimc banks deposits, but in the short run does not have a significant effect on the deposits of Islamic banks.
\end{abstract}

Keywords: Islamic Banks, Deposits, MonetaryPolicy, Macroeconomic

\section{PENDAHULUAN}

\section{Latar Belakang}

Bank syariah merupakan lembaga keuangan atau perbankan yang operasionalnya tidak mengunakan sistem bunga melainkan menggunakan prinsip bagi hasil atau profit losssharing(PLS) (Muhammad, 2002:12). Hal ini sejalan dengan perintah Allah dalam Al-Qur'an untuk menghindari sistem bunga atau riba'. Firman Allah dalam Al-Qur'an surat Al-Imran Ayat 130 :

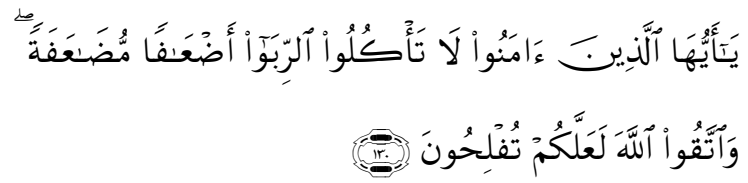

Artinya : "Hai orang-orang yang beriman, janganlah kamu memakan Riba dengan berlipat ganda dan bertakwalah kamu kepada Allah supaya kamu mendapat keberuntungan". (QS. Al-Imran :130).
Perkembangan bank syariah telah berkembang cukup pesat di beberapa negara. Menurut Participans Bank (2009), lebih dari 300 institusi dalam 80 negara mendirikan bank syariah atau bank bebas bunga. Bank syariah di Indonesia sendiri terus mengalami perkembangan sejak diresmikannya pada tahun 1992 sampai saat ini. Perkembangan ini terlihat Baik dari sisi total aset, pembiayaan, dan dana pihak ketiga. Perkembangan bank syariah ini menunjukkan bahwa masyarakat dari tahun ke tahun semakin percaya dengan adanya kinerja dan performa yang ditunjukkan oleh perbankan syariah. Berikut adalah perkembangan DPK bank syariah dari tahun 2010-2015:

\footnotetext{
1) Jurnal ini merupakan bagian dari skripsi yang ditulis olehMohammad Abdul Adim, NIM: 041211431153 , yang diuji pada 11 Agustus 2016
} 
Adim, et al/Jurnal Ekonomi Syariah Teori dan Terapan Vol. 4 No. 8 Agustus 2017: 642-656; Pengaruh Guncangan Kebijakan Moneter dan Variabel Makro Terhadap Dana Pihak Ketiga (DPK) Bank Syairah di Indonesia

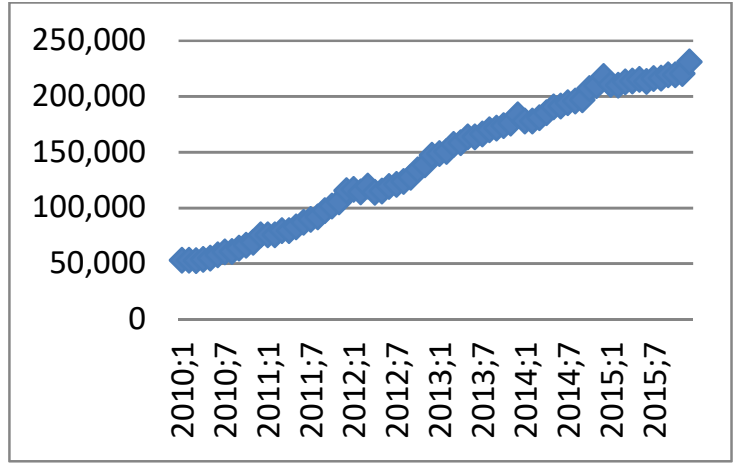

Sumber : Statistik perbankan Syariah (SPS).

Gambar 1.

Perkembangan DPK Bank Syariah

Tahun 2010-2015

Penghimpunan dana pihak ketiga

oleh bank syariah tidak selalu berada pada kondisi yang optimal, penghimpunan DPK ini juga menghadapi beberapa masalah, salah satunya adalah kebijakan moneter. Haron dan Azmi (2008) serta Kasim etal.(2009) menjelaskan bahwa fluktuasi dana pihak ketiga bank syariah tidak hanya dipengaruhi oleh margin atau keuntungan di bank syariah, tetapi juga dipengaruhi oleh perubahan suku bunga di bank konvensional dan perubahan kebijakan moneter.

Penerapan dual banking system yang dianut oleh Indonesia ini akan membuat hubungan yang erat antara kebijakan moneter yang dilakukan oleh Bank Indonesia dan bank syariah. Pasalnya, instrumen utama yang diberlakukan oleh Bank Indonesia dalam menjalankan kebijakan moneter yaitu $\mathrm{BI}$ Rate yang masih berbasis bunga. sehingga akan memiliki dampak terhadap bank syariah.

Suku bunga kebijakan moneter Bank Indonesia (BI Rate) merupakan salah satu instrumen kebijakan moneter yang digunakan sebagai suku bunga acuan bank konvensional. Ketika Bank Indonesia menaikkan suku bunga kebijakan moneter (BI Rate), maka suku bunga bank konvensional juga akan meningkat. Hal ini akan akan membuat nasabah lebih memilih menabung di bank konvensional daripada di bank syariah karena keuntungan yang lebih besar. Hal ini secara tidak langsung akan berpengaruh terhadap bank syariah.

Penghimpunan dana pihak ketiga yang dilakukan oleh bank syariah juga dipengaruhi oleh beberapa variabel makro, seperti inflasi, jumlah uang beredar (M2), dan produk domestik bruto (Haron dan Azmi, 2008). Inflasi dapat diartikan sebagai kenaikan harga secara terus menerus dari barang-barang dan jasa secara umum. Ketika terjadi inflasi, maka akan terjadi ketidakpastian kondisi ekonomi suatu negara yang mengakibatkan masyarakat lebih menggunakan uang mereka untuk konsumsi. Tigginya harga dan tidak diikuti dengan kenaikan pendapatan membuat masyarakat tidak mempunyai kelebihan dana untuk disimpan dalam bentuk tabungan atau diinvestasikan. Pernyataan ini didukung oleh penelitian yang dilakukan oleh Muhammad Abduh dkk (2011) yang menyebutkan bahwa inflasi memiliki pengaruh terhadap deposito bank syariah di Malaysia.

Menurut Mankiw (2003:153) produk domestik bruto adalah nilai pasar dari semua barang dan jasa akhir yang 
Adim, et al/Jurnal Ekonomi Syariah Teori dan Terapan Vol. 4 No. 8 Agustus 2017: 642-656; Pengaruh Guncangan Kebijakan Moneter dan Variabel Makro Terhadap Dana Pihak Ketiga (DPK) Bank Syairah di Indonesia

diproduksi dalam suatu negara pada periode tertentu. Peningkatan produk domestik bruto ini tercermin dari peningkatan pendapatan masyarakat. Peningkatan pendapatan ini akan memiliki pengaruh terhadap kemampuan masyarakat untuk menabung. sehingga peningkatan pendapatan akan berpengauh pada DPK bank syariah. Hal ini didukung oleh penelitian yang dilakukan oleh Yusof dan Rodney (2005) yang menyatakan PDB memiliki pengaruh terhadap dana pihak ketiga bank syariah di Malaysia.

Jumlah vang beredar adalah nilai keseluruhan vang yang berada di tangan masyarakat dan yang ada di bank. Secara teoritis, peningkatan jumlah vang beredar yang ada di masyarakat akan menyebabkan turunnya suku bunga kredit dan terdepresiasinya nilai mata vang. Penurunan pada tingkat suku bunga kredit ini akan meningkatkan konsumsi masyarakat karena masyarakat akan lebih memilih meminjam vang di bank daripada menabung karena biaya pinjaman yang rendah. Sehingga akan berpengaruh pada dana pihak ketiga bank syariah.penelitian yang dilakukan oleh Yusof (2008) yang menyatakan bahwa jumlah vang beredar memiliki pengaruh terhadap dana pihak ketiga bank syariah di Malaysia dan di Bahrain.

Berdasarkan uraian diatas, rumusan masalah yang diajukan dalam penelitian ini adalah

1. Bagaimanakah hubungan variabel Kebijakan Moneter (BI Rate), Produk
Domestik Bruto (PDB), Jumlah Uang Beredar (M2), Indeks Harga Konsumen (IHK) terhadap Dana Pihak Ketiga (DPK) bank syariah dalam jangka panjang dengan metode Johansen Cointegration?

2. Bagaimanakah hubungan variabel Kebijakan Moneter (BI Rate), Produk Domestik Bruto (PDB), Jumlah Uang Beredar (M2), Indeks Harga Konsumen (IHK) terhadap Dana Pihak Ketiga (DPK) bank syariah dalam jangka pendek dengan metode Impulse Response Function?

\section{LANDASAN TEORI}

Definisi bank syariah dapat merujuk pada salah satu pengertian yang dinyatakan oleh Ascarya (2006:32) yaitu:

Bank Islam atau di Indonesia disebut dengan bank syariah adalah merupakan lembaga keuangan yang berfungsi memperlancar mekanisme ekonomi di sektor riil melalui aktivitas kegiatan usaha (investasi, jual beli, atau lainnya) berdasarkan prinsip Syariah, yaitu aturan perjanjian berdasarkan hukum Islam antara bank dan pihak lain untuk penyimpanan dana dan atau pembiayaan kegiatan usaha, atau kegiatan lainnya yang dinyatakan sesuai dengan nilai-nilai Syariah yang bersifat makro maupun mikro.

Selain itu, pengertian prinsip syariah menurut Pasal 1 ayat 13 Undang-undang No.10 tahun 1998 tentang perbankan syariah adalah aturan perjanjian berdasarkan hukum Islam antara bank dengan pihak lain untuk penyimpanan dana atau pembiayaan kegiatan usaha, atau kegiatan lainnya yang dinyatakan sesuai dengan prinsip syariah antara lain pembiayaan dengan menggunakan atau 
Adim, et al/Jurnal Ekonomi Syariah Teori dan Terapan Vol. 4 No. 8 Agustus 2017: 642-656; Pengaruh Guncangan Kebijakan Moneter dan Variabel Makro Terhadap Dana Pihak Ketiga (DPK) Bank Syairah di Indonesia

berdasarkan prinsip bagi hasil (mudharabah), pembiayaan berdasarkan prinsip penyertaan modal (musyarakah), prinsip jual beli barang dengan keuntungan (murabahah), atau pembiayaan barang model berdasarkan prinsip sewa murni tanpa pilihan (ijarah), atau dengan adanya pilihan pemindahan kepemilikan atas barang yang disewakan (ijarah waiqtima).

$$
\text { Layaknya lembaga keuangan }
$$

pada umumnya, bank syariah juga memiliki alur operasional dalam menjalankan fungsinya sebagai lembaga intermediary. Ascarya menjelaskan bahwa alur operasional bank syariah dimulai dengan menghimpun dana melalui prinsip wadiah yad dhamanah, mudharabah mutlaqah, ijarah, dan lain-lain, serta setoran modal dimasukkan ke dalam poolingfund. Pooling fund ini kemudian dipergunakan dalam penyaluran dana dalam bentuk pembiayaan dengan prinsip bagi hasil, jual beli, dan sewa. Dari pembiayaan dengan prinsip bagi hasil diperoleh bagian bagi hasil/laba sesuai kesepakatan awal (nisbah bagi hasil) dengan masing-masing nasabah (mudharib atau mitra usaha); dari pembiayaan dengan prinsip jual beli diperoleh margin keuntungan; sedangkan dari pembiayaan dengan prinsip sewa diperoleh pendapatan sewa. Keseluruhan pendapatan dari pooling fund ini kemudian dibagihasilkan antara bank dengan semua nasabah yang menitipkan, menabung, atau menginvestasikan uangnya sesuai dengan kesepakatan awal. Bagian nasabah atau hak pihak ketiga akan didistribusikan kepada nasabah, sedangkan bagian bank akan dimasukkan ke dalam laporan rugi laba sebagai pendapatan operasi utama. Sementara itu, pendapatan lain, seperti dari mudharabah muqayyadah (investasi terikat) dan jasa keuangan dimasukkan ke dalam laporan rugi laba sebagai pendapatan operasi lainnya.

Perbankan syariah memerlukan dana untuk menjalankan operasionalnya, sehingga kegiatan bank syariah dalam mengumpulkan dana dari masyarakat sangatlah penting untuk dilakukan. Menurut Muhammad (2002:49), sumber dana bank syariah yang digunakan sebagai alat opersionalnya terdiri dari dana-dana sebagai berikut:

1. Dana Pihak Kesatu Dana pihak kesatu adalah dana yang berasal dari pemilik modal atau modal dari bank itu sendiri. Dana ini berasal dari dana pemilik bank dan para pemegang saham.

2. Dana Pihak Kedua Dana pihak kedua adalah danadana pinjaman yang berasal dari pihak luar. Perolehan dana dari sumber ini berasal dari pinjaman antar bank (callmoney), pinjaman dari lembaga kevangan lain dan pinjaman dari bank sentral.

3. Dana Pihak Ketiga

Dana pihak ketiga adalah dana yang berasal dari masyarakat. Dana-dana ini dihimpun oleh bank syariah melalui produk yang dikeluarkan oleh bank syariah. Dana pihak ketiga ini merupakan dana terbesar yang dimiliki oleh bank syariah mencapai $80 \%-90 \%$ dari seluruh dana yang dikelola bank syariah. 
Adim, et al/Jurnal Ekonomi Syariah Teori dan Terapan Vol. 4 No. 8 Agustus 2017: 642-656; Pengaruh Guncangan Kebijakan Moneter dan Variabel Makro Terhadap Dana Pihak Ketiga (DPK) Bank Syairah di Indonesia

BI Rate yakni suku bunga dengan tenor satu bulan yang diumumkan setiap awal bulan oleh Bank Indonesia untuk jangka waktu tertentu. BI Rate digunakan sebagai sasaran operasional ditujukan sebagai respon dari kebijakan monter untuk mengarahkan agar pergerakan inflasi dan ekonomi ke depan tetap berada pada jalur pencapaian inflasi yang telah ditetapkan. Bl Rate ini ditetapkan oleh rapat dewan gubernur (RDG) dan diumumkan kepada publik pada wala bulan.

Produk domestik Bruto (PDB) adalah nilai pasar dari semua barang dan jasa akhir yang diproduksi dalam suatu negara pada periode tertentu (Mankiw, 2003:157). Secara teoritis perhitungan PDB dilakukan dengan tiga cara, yakni: pendekatan produksi, pendapatan dan pengeluaran. BPS (2016) menjelaskan bahwa:

PDB pada dasarnya merupakan jumlah nilai tambah yang dihasilkan oleh seluruh unit usaha dalam suatu negara tertentu, atau merupakan jumlah nilai barang dan jasa akhir yang dihasilkan oleh seluruh unit ekonomi". Perhitungan Produk Domestik Bruto (PDB) biasanya menggunakan interval waktu satu tahun.

Dalam perhitungan Produk Domestik Bruto (PDB) biasanya menggunakan dua dasar perhitungan. Pertama, atas dasar harga berlaku atau PDB Nominal yaitu dengan menggunakan harga pasar yang berlaku tiap tahun. Perhitungan Produk Domestik Bruto (PDB) yang kedua, yaitu atas dasar harga konstan atau PDB riil yaitu dengan menggunakan harga pasar yang berlaku pada tahun tertentu sebagai dasar perhitungan. Harga pasar mengukur tingkat kerelaan konsumen dalam membayar suatu barang, maka harga pasar dapat mencerminkan nilai barang tersebut.

Rahardja dan Manurung (2004:182), menjelaskan bahwa jumlah vang beredar dalam arti sempit (narrow money) adalah seluruh vang kartal (uang tunai) yang dipegang masyarakat dan vang giral yang dimiliki oleh masyarakat pada bank-bank umum seperti giro. Selanjutnya, Rahardja dan Manurung (2004:182) juga menjelaskan bahwa jumlah vang beredar dalam arti luas (broad money) atau M2 adalahjumlah vang beredar dalam arti sempit ditambah dengan uang kuasi seperti deposito berjangkan dan tabungan.

Inflasi dalam penelitian ini di proksikan dengan variabel Indeks Harga Konsumen (IHK), yaitu indeks yang mengukur rata-rata perubahan harga antar waktu dari suatu paket jenis barang dan jasa yang dikonsumsi oleh penduduk atau rumah tangga di daerah perkotaan dengan dasar suatu periode tertentu (www.bps.go.id).

Beberapa penelitian yang menjadi dasar dalam penelitian ini, miesalnya saja penelitian yang dilakukan oleh Hakam dan Gulumser (2011) dengan judul "Impact of Interest Rate on Islamic and Conventional Banks: The case of Turkey". Hasilnya menyatakan bahwa suku bunga kebijakan moneter berpengaruh negatif 
Adim, et al/Jurnal Ekonomi Syariah Teori dan Terapan Vol. 4 No. 8 Agustus 2017: 642-656; Pengaruh Guncangan Kebijakan Moneter dan Variabel Makro Terhadap Dana Pihak Ketiga (DPK) Bank Syairah di Indonesia

terhadap deposito bank syariah di Turkey dan berpengaruh positif terhadap pembiayaan bank syariah dan juga deposito bank konvensional.

Penelitian yang dilakukan oleh Yusoff dan Rodney (2005) yang berjudul" An Econometric Analisis of Conventional and Islamic Bank Deposits in Malaysia". Hasil penelitian ini menyebutkan bahwa produk domestik bruto berpengaruh positif terhadap dana pihak ketiga bank syariah. Yusoff dan Rodney (2005) menjelaskan bahwa terhadap hubungan yang searah antara variabel PDB dan dana pihak ketiga bank syariah.

Penelitian yang dilakukan oleh Yusof (2008). Penelitian yang berjudul "Monetary Policy Shock and Islamic Banks' Deposits In A Dual Banking System: A Comparative Analysis Between Malaysia And Bahrain". Hasil penelitian tersebut menyebutkan bahwa jumlah vang beredar (M2) berpengaruh positif dan signifikan terhadap deposito bank syariah di Bahrain tetapi tidak berpengaruh signifkan pada deposito bank syariah di Malaysia.

Selanjutnya, penelitian yang dilakukan oleh Muhammad Abduh dkk (2011) yang berjudul "The Impact of Crisis and Macroeconomic Variables towards Islamic banking Deposits". Hasil penelitian ini menyatakan bahwa perubahan tingkat suku bunga dan inflasi memiliki dampak negatif dan signifikan terhadap deposito bank syariah. sedangkan tingkat keuntungan, dan pertumbuhan produksi memiliki pengaruh yang positif dan signifikan terhadap deposito bank syariah.

Berdasarkan latar belakang, rumusan masalah, tujuan penelitian, landasan teori, dan penelitian terdahulu yang telah dikemukakan maka hipotesis dalam penelitian ini adalah:

H1: Diduga terdapat hubungan jangka panjangantara variabel Kebijakan Moneter (BI Rate), Produk Domestik Bruto (PDB), Jumlah Uang Beredar (M2), Indeks Harga Konsumen (IHK) dan Dana Pihak Ketiga (DPK) Bank Syariah.

$\mathrm{H}: 2$ Diduga terdapat hubungan jangka pendekantara variabel Kebijakan Moneter (BI Rate), Produk Domestik Bruto (PDB), Jumlah Uang Beredar (M2), Indeks Harga Konsumen (IHK) dan Dana Pihak Ketiga (DPK) Bank Syariah.

Untuk menjawab rumusan masalah yang telah dirumuskan dan untuk membuktikan hipotesis yang telah ditentukan, maka penulis membuat sebuah model analisis agar lebih mudah dalam mejawab rumusan masalah dan hipotesis. Berikut adalah model analisis dalam penelitian ini:

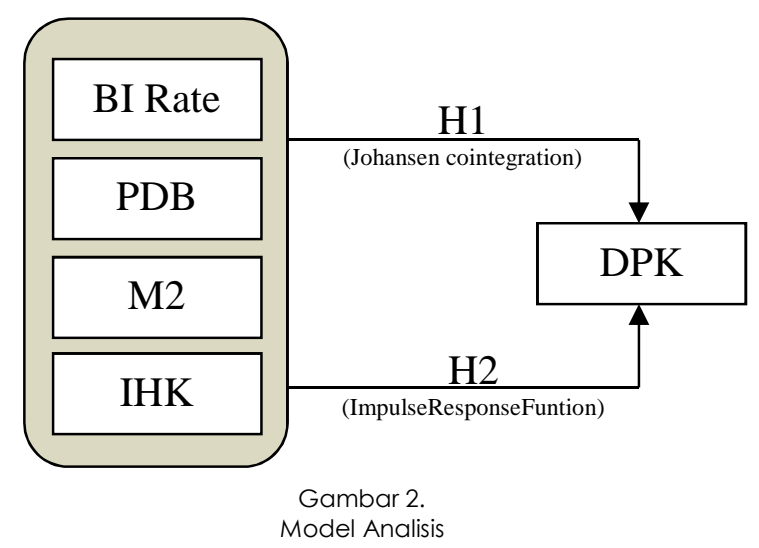


Adim, et al/Jurnal Ekonomi Syariah Teori dan Terapan Vol. 4 No. 8 Agustus 2017: 642-656; Pengaruh Guncangan Kebijakan Moneter dan Variabel Makro Terhadap Dana Pihak Ketiga (DPK) Bank Syairah di Indonesia

Pada penelitian ini, penulis menggunakan metode Johansen Cointegration untuk mencari hubungan jangka panjang antara variabel yang diteliti. Berdasarkan rumusan masalah dan hipotesis, untuk menjawab hubungan jangka pendek dalam hipotesis kedua, penulis menggunakan metode Impulse Response Function(IRF) dan Variance Decompotition(VD).

\section{METODE PENELITIAN}

\section{Pendekatan penelitian}

Pendekatan yang digunakan dalam penelitian ini adalah pendekatan kuantitatif. Alat analisis kuantitatif yang digunakan dalam penelitian ini adalah Johansen Cointegration dan Vector Autoregressive (VAR).

\section{Variabel Dependen}

1. Dana Pihak Ketiga Bank Syariah

Merupakan dana yang dihimpun dari masyarakat luas sebagai nasabah pendanaan. Jenis Dana Pihak Ketiga ini terdiri dari, pertama adalah Giro (demanddeposits). Kedua adalah tabungan (savingdeposits). Ketiga adalah deposito (invesmentdeposits). Data DPK ini diperoleh dari Statistik Perbankan Syariah (SPS) dengan satuan miliar rupiah dari periode 2005:Q1 sampai dengan 2015:Q4.

\section{Variabel Independen}

2. BI Rate

Merupakan instrumen kebijakan moneter yang digunakan oleh Bank Indonesia dalam mempengaruhi jumlah vang beredar dan inflasi. Suku bunga kebijakan moneter (BIRate) ini ditetapkan dalam Rapat Dewan Gubernur (RDG) dan dikeluarkan oleh $\mathrm{BI}$ setiap bulan sebagai sinyal kebijakan moneter. Data yang digunakan dalam penelitian ini adalah $\mathrm{BI}$ Rate dengan periode triwulanan dengan satuan presentase (\%) dari periode 2005:Q1- 2015:Q4 yang diperoleh dari Bank Indonesia.

3. Produk Domestik Bruto

Produk Domestik Bruto (PDB) adalah jumlah barang dan jasa akhir yang dihasilkan oleh seluruh unit ekonomi suatu negara pada periode tertentu. Penelitian ini menggunakan PDB dengan harga konstan $(2000=100)$ dengan satuan miliar rupiah. Periode data PDB ini berupa data triwulanan dimulai dari tahun 2005:Q12015:Q4 yang diperoleh dari Statistik Ekonomi dan Keuangan Indonesia (SEKI).

4. Jumlah Uang Beredar (M2)

Merupakan jumlah uang yang beredar di masyarakat (M1) ditambah dengan vang quasi. Data jumlah uang beredar ini diperoleh dari Badan Pusat Statistik dengan periode triwulanan dari periode 2005:Q1 sampai dengan 2015:Q4 yang dinyatakan dalam satuan miliar rupiah.

5. Indeks Harga Konsumen (IHK)

Indeks Harga Konsumen adalah salah satu indikator makro ekonomi yang memberikan informasi mengenai harga barang dan jasa yang dibayar oleh konsumen. Indeks Harga Konsumen (IHK) secara umum digunakan sebagai indikator patokan dalam mencari nilai inflasi. Data yang digunakan dalam penenlitian ini adalah data Indeks Harga Konsumen (IHK) yang dinyatakan dalam 
Adim, et al/Jurnal Ekonomi Syariah Teori dan Terapan Vol. 4 No. 8 Agustus 2017: 642-656; Pengaruh Guncangan Kebijakan Moneter dan Variabel Makro Terhadap Dana Pihak Ketiga (DPK) Bank Syairah di Indonesia

bentuk indeks dengan periode triwulanan dari periode 2005:Q1 sampai dengan 2015:Q4 yang diperoleh dari Badan Pusat Statistik (BPS).

\section{Jenis dan Sumber Data}

Jenis data yang digunakan dalam penelitian ini adalah data sekunder berupa data timeseries. Data sekunder dalam penelitian ini berasal dari pihak lain selain peneliti. Data sekunder yang digunakan dalam penelitian ini berasal dari laporan historis yang telah disusun dan dipublikasikan oleh beberapa lembaga seperti Badan Pusat Statistik (BPS) Indonesia di website resminya www.bps.go.id. Dan Data yang terdapat di SEKI Bank Indonesia. Data yang digunakan dalam penelitian ini berupa data kuartalan yang memiliki rentang waktu antara tahun 2005:Q1 sampai dengan tahun 2015:Q4.

\section{Populasi dan Sampel}

Populasi dalam penelitian ini adalah semua perbankan syariah yang ada atau industri perbankan syariah di Indonesia. Untuk pemilihan sampel, metode yang digunakan adalah metode sampel jenuh, yaitu seluruh populasi digunakan sebagai sampel. Berdasarkan metode pemilihan sampel yang dipilih, maka sampel dari penelitian ini adalah seluruh bank syariah yang ada di Indonesia.

Data yang terkumpul dan digunakan dalam penelitian ini berasal dari beberapa data publikasi beberapa lembaga, yaitu Badan Pusat Statistik (BPS) dan Bank Indonesia yang dikumpul dari website resmi masing-masing lembaga.
Data yang terkumpul merupakan data publikasi resmi yang telah diarsipkan oleh masing-masing lembaga sehingga bersifat valid.

\section{Teknik Analisis}

Teknik analisis yang digunakan dalam penelitian ini adalah metode Johansen Cointegration dan Vektor Autoregressive (VAR). Metode VAR ini merupakan salah satu metode analisis data timeseries yang bersifat ateoritik. Program komputer yang digunakan dalam penelitian ini terkait dengan analisis yang digunakan adalah program EViews versi 9. Penelitian ini menggunakan tingkat signifikansi (a) sebesar lima persen (5\%).

Berikut adalah langkah-langkah yang dilakukan.

1. Uji Stasioneritas Data

2. Pemilihan Lag Optimum

3. Uji Johansen Cointegration

4. Uji Model VAR

- Impulse response Function

- Variance Decompotition

\section{IV.HASIL dan PEMBAHASAN}

\section{Hasil Uji Stasioneritas Data}

Berdasarkan hasil uji stasioneritas dengan menggunakan uji ADF pada tingkat level intercept, intercept and trend, variabel DPK stasioner pada tingkat $a=5 \%$, variabel PDB stasioner pada $a=$ $1 \%$, variabel $\mathrm{BI}$ Rate stasioner pada $\mathrm{a}=$ $10 \%$, dan variabel IHK stasioner pada $a=$ $5 \%$, hal ini dikarenakan nilai ADF t-statistik lebih besar daripada Mackinnon Critical Valve. Uji stasioneritas (unit root) dengan menggunakan ADF selanjutnya adalah 
Adim, et al/Jurnal Ekonomi Syariah Teori dan Terapan Vol. 4 No. 8 Agustus 2017: 642-656; Pengaruh Guncangan Kebijakan Moneter dan Variabel Makro Terhadap Dana Pihak Ketiga (DPK) Bank Syairah di Indonesia

pada tingkat first (1st) difference. Hasilnya terlihat bahwa semua variabel telah stasioner baik pada intercept maupun trendandintercept. Secara keseluruhan, variabel yang akan diuji menggunakan ADF telah stasioner pada tingkat firstdifference.

Selain menggunakan uji ADF, penelitian ini juga menggunakan uji unit root dengan metode Philips-Perron (PP). Pada metode PP tingkat level baik dengan intercept dan intercepr dan trend, variabel yang stasioner adalah variabel PDB dan M2 masing-masing pada $a=1 \%$ dan variabel IHK pada $a=5 \%$, sedangkan pada firstdifferent, terlihat semua variabel telah stasioner pada $a=$ $1 \%$.

\section{Hasil Penentuan Lag Optimum}

Penentuan lag optimal menggunakan empat kriteria, yaitu : Final Prediction Error (FPE), Akaike Information Critirion (AIC), Schawrz Information (SIC) dan Hannan-Quinn Information Critirion (HQ). Dari hasil pengujian lag optimal dengan menggunakan Eviews 9 ditemukan bahwa dari keempat kriteria informasi, tiga diantaranya memberikan tanda bintang (*) pada lag 3, yaitu Prediction Error (FPE), Akaike Information Critirion (AIC), dan Hannan-Quinn Information Critirion (HQ). Sedangkan kriteria informasi Schawrz Information (SIC) menunjukkan pada lag 1. Berdasarkan hasil yang telah dianalisis, maka dapat diketahui bahwa panjang lag yang disarankan oleh eviews adalah lag 3.

\section{Hasil Uji Kointegrasi}

Berdasarkan pada hasil uji Johansen Cointegration menggunakan eviews 9 menunjukkan bahwa terdapat dua persamaan kointegrasi. Pernyataan tersebut dapat dilihat dari nilai trace statistik dan Max-Eighenvalue yang lebih besar dari nilai kritisnya pada tingkat alpha 5\%. Nilai trace statistik yang lebih besar dari nilai kritsnya yaitu112.2621 > 79.34145, dan $64.73009>55.24578$. Selain itu, pada nilai Max-Eighen lebih besar dari nilai kritisnya yaitu nilai Max-Eighen sebesar 47.53196 yang lebih besar dari nilai kritsnya yaitu 37.16359. hasil tersebut dapat disimpulkan bahwa terdapat kointegrasi dalam variabel yang akan diteliti.

Salah satu fungsi uji Johansen Cointegration ini adalah untuk mengestimasi hubungan jangka panjang antar variabel dalam penelitian. Berdasarkan hasil uji Johansen Cointegration dengan menggunakan eviews 9.0 ini didapatkan nilai normalize sebagai berikut:

LDPK $=46,15409$ LPDB $-159,0029$ BI Rate - 24,91641

LM2 - 43,23350 LIHK

Berdasarkan pada persamaan jangka panjang diatas, dapat diketahui hubungan antara variabel dalam jangka panjang. Hubungan positif terjadi pada hubungan antara PDB dan DPK. Artinya, peningkatan pada PDB maka akan meningkatkan dana pihak ketiga bank syariah. Terdapat hubungan negatif antara BI Rate dan DPK. Hal ini berarti bahwa jika terjadi peningkatan pada suku bunga Bank Indonesia maka akan diikuti dengan penurunan dana pihak ketiga 
Adim, et al/Jurnal Ekonomi Syariah Teori dan Terapan Vol. 4 No. 8 Agustus 2017: 642-656; Pengaruh Guncangan Kebijakan Moneter dan Variabel Makro Terhadap Dana Pihak Ketiga (DPK) Bank Syairah di Indonesia

bank syariah. selain itu, juga terjadi hubungan yang negatif antara jumlah vang beredar dan DPK bank syariah dalam jangka panjang. Hubungan negatif juga terjadi antara variabel Indeks Harga Konsumen (IHK) dan DPK bank syariah dalam jangka panjang.

\section{Hasil Uji ImpulseResponseFunction (IRF)}

Penggunaan Impulse Response Function ini bertujuan untuk memperoleh hubungan jangka pendek antara variabel dalam penelitian. Sehingga nantinya dapat diketahui respon masing-masing variabel terhadap guncangan atau perubahan variabel lain yang ada dalam penelitian. Berikut adalah hasil Impulse Response Function dalam penenlitian ini:

Re spon se of DLDPK to DLPDB

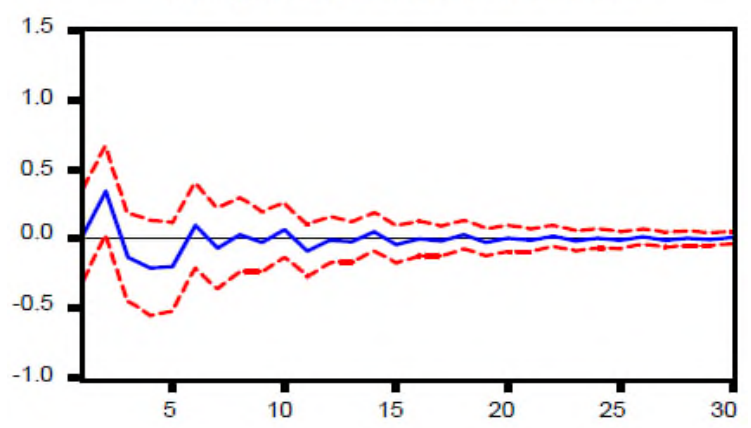

Gambar 3.

Respon DPK terhadap Guncangan PDB

Pada gambardiatas, terlihat hubungan antara variabel DPK bank syariah dan produk domestik bruto. Pada periode awal, dana pihak ketiga bank syariah merespon positif guncangan produk domestik bruto dari periode pertama sampai periode kedua. Setelah itu, respon PDK menjadi negatif sampai periode keenam. Respon DPK bank syariah terhadap PDB ini terus mengalami fluktuatif dari peridoe ke 6 hingga periode ke 15. Setelah periode ke 15, respon DPK terhadap guncangan PDB ini menjadi positif sampai akhir periode penelitian. Secara keseluruhan dapat ditarik kesimpulan bahwa dalam jangka pendek terdapat hubungan positif antara produk domestik bruto dan DPK bank syariah.

Resp onse of DLDPK to DBI_RATE

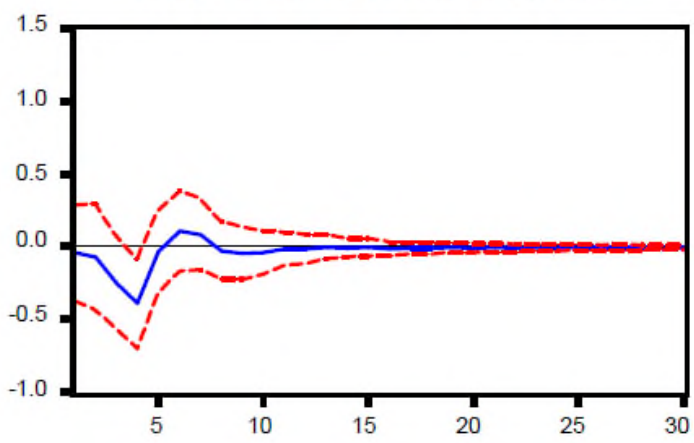

Gambar 4.

Respon DPK terhadap Guncangan BI Rate

Dana pihak ketiga bank syariah merespon negatif guncangan pada variabel $\mathrm{BI}$ Rate. Artinya, ketika terjadi peningkatan pada variabel BI Rate maka akan direspon negatif oleh DPK bank syariah. Pada gambar terlihat bahwa dana pihak ketiga bank syariah merespon negatif guncangan Bl Rate dari awal periode sampai dengan periode ke enam. Setelah itu,DPK bank syariah ini berubah respon menjadi positif pada periode keenam sampai ke tujuh. Setelah itu, DPK bank syariah berubah respon menjadi negatif sampai akhir periode penelitian. Tingkat signifikansi dapat ditunjukkan dengan standar error (garis merah) yang menyentuh garis tengah pada periode ke empat. Hal Ini menunjukkan bahwa $\mathrm{Bl}$ rate memiliki 
Adim, et al/Jurnal Ekonomi Syariah Teori dan Terapan Vol. 4 No. 8 Agustus 2017: 642-656; Pengaruh Guncangan Kebijakan Moneter dan Variabel Makro Terhadap Dana Pihak Ketiga (DPK) Bank Syairah di Indonesia

hubunganyang nehatif dan signifikan dengan Dana Pihak Ketiga (DPK) bank syariah dalam jangka pendek.

Selanjutnya adalah respon Dana Pihak Ketiga bank syariah terhadap guncangan variabel Jumlah Uang Beredar (M2), yaitu :

Re spon se of DLDPK to DLM 2

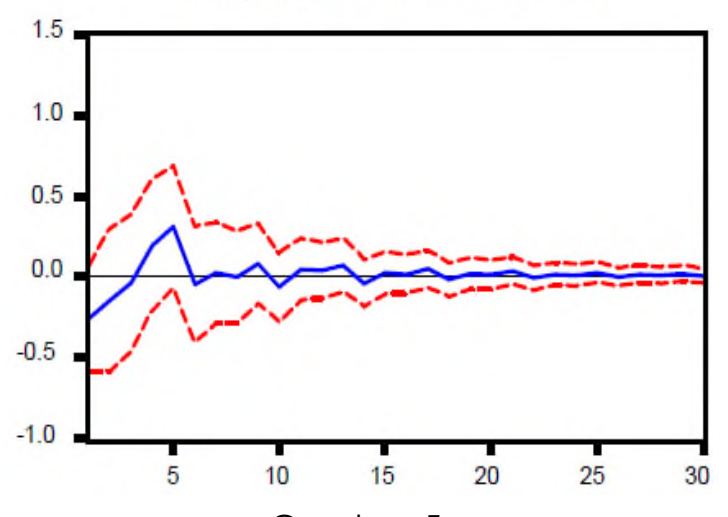

Gambar 5.

Respon DPK terhadap Guncangan M2

Pada gambar diatas, menunjukkan respon dana pihak ketiga bank syariah terhadap guncangan jumlah vang beredar (M2) dalam jangka pendek. Terlihat bahwa DPK merespon negatif guncangan M2 pada awal periode sampai periode ketiga. Setelah itu, respon DPK berubah menjadi positif hingga periode kesepuluh. Pada periode kesepuluh ini, variabel DPK bank syariah kembali merespon negatif guncangan M2. Respon positif ditunjukkan oleh DPK setelah periode kesepuluh sampai akhir periode penelitian. Akan tetapi, dapat dilihat bahwa standar error (garis merah putus-putus) tidak menyentuh garis tengah dalam periode penelitian. Hal tersebut menandakan adanya pengaruh yang tidak signifikan. Secara keseluruhan, dalam jangka pendek Dana Pihak Ketiga
(DPK) bank syariah merespon positif guncangan pada variabel Jumlah Uang Beredar (M2). Sehingga dapat ditarik sebuah kesimpulan bahwa terdapat hubungan positif tidak signifikan antara Dana Pihak Ketiga (DPK)banks syariah dan Jumlah Uang Beredar (M2) dalam jangka pendek.

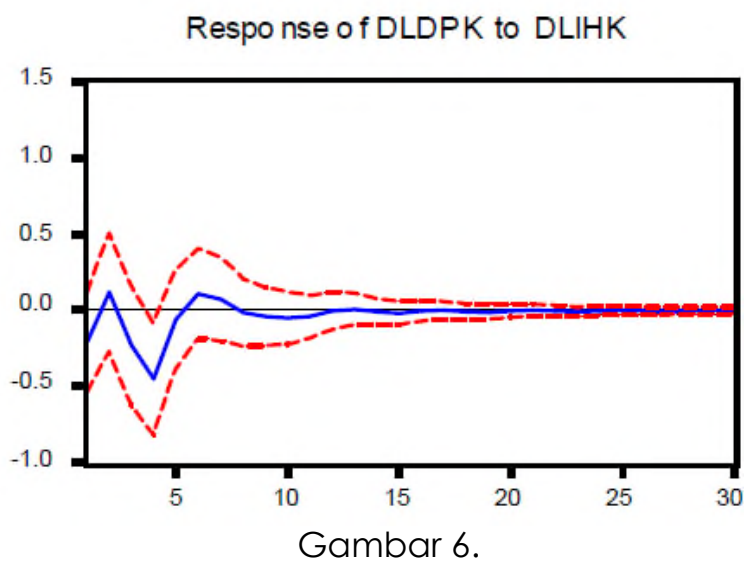

Respon DPK terhadap Guncangan IHK

Pada gambar diatas, menunjukkan respon dana pihak ketiga bank syariah (DPK) terhadap guncangan variabel indeks harga konsumen atau inflasi. Respon DPK terhadap guncangan variabel IHK pada awal periode adalah merespon negatif yaitu pada periode ketiga sampai dengan periode kelima. DPK merespon positif guncangan variabel IHK pada periode keenam sampai ketujuh. Setelah peridoe ketujuh, respon DPK terhadap guncangan variabel IHK menjadi negatif sampai akhir periode. Terlihat bahwa garis standar error menyentuh garis tengah pada periode penelitian. sehingga,dapat disimpulkan bahwa variabel IHK atau inflasi memiliki hubungan yang negatif dan signifikan dengan dana pihak ketiga bank syariah (DPK) dalam jangka pendek. 
Adim, et al/Jurnal Ekonomi Syariah Teori dan Terapan Vol. 4 No. 8 Agustus 2017: 642-656; Pengaruh Guncangan Kebijakan Moneter dan Variabel Makro Terhadap Dana Pihak Ketiga (DPK) Bank Syairah di Indonesia

\section{Pembahasan}

1. Pengaruh Produk Domestik Bruto (PDB) Terhadap DPK Bank Syariah

Baik dalam jangka panjang maupun jangka pendek, terdapat hubungan positif dan signifikan antara DPK bank syariahdan Produk Domestik Bruto (PDB).

Hal ini menendakan bahwa ketika terjadi peningkatan pada Produk Domestik Bruto (PDB), maka dana pihak ketiga bank syariah juga akan meningkat juga. Hasil ini sesuai dengan penelitian yang dilakukan oleh Haron dan Azmi (2008), Sahliyah (2015), Affandi (2010), Kasri dan Kassim (2009), dan Nwachukwu dan Egwaikhide (2007).

Hal ini dapat dijelaskan bahwa pertumbuhan ekonomi yang bagus sangat penting untuk mendukung perkembangan perbankan syariah. Tingginya produk domestik bruto menunjukkan bahwa kondisi perekonomian dalam kondisi baik dan stabil. Pada kondisi PDB yang tinggi ini tercermin pendapatan masyarakat yang tinggi. Sahliyah (2015)menjelaskan bahwa Ketika pendapatan masyarakat yang tinggi maka masyarakat memiliki kemampuan yang lebih untuk manabung. Sehingga Dana pihak ketiga bank syariah meningkat.

2. Pengaruh Kebijakan Moneter (BI Rate) Terhadap DPK Bank Syariah

Baik dalam jangka panjang maupun jangka pendek, variabel DPK merespon negatif guncangan pada BI Rate. artinya terdapat hubungan negatif dan signifikan antara DPK bank syariah dan BI Rate. Peningkatan $\mathrm{Bl}$ Rate akan menyebabkan dana pihak ketiga mengalami penurunan. Hasil ini sesuai dengan penelitian yang dilakukan oleh Huseyin Cetin (2014), Hakan dan Gulumser (2011) dan Sukmana dan Kassim (2010).

Ketika terjadi peningkatan pada BI Rate, maka dalam jangka pendek bank konvensional akan segera menaikkan suku bunga deposito dan suku bunga kredit. Karena pada dasarnya suku bunga kebijakan moneter (BI Rate) yang dikelvarkan oleh Bank Indonesia ini dijadikan sebagai suku bunga acuan oleh konvensional. Pergerakan dari suku bunga bank konvensional akan mengikuti pergerakan dari BI Rate.

Hakan dan Gulumser (2011) menjelaskan bahwa tingginya suku bunga deposito bank kkonvensional akan membuat nasabah bank syariah memilih menempatkan dananya pada bank konvensional karena keuntungan yang lebih besar, sehingga nasabah akan menarik dananya dari bank syariah dan menempatkan dananya pada bank syariah atau disebut dispalce commercial risk.

3. Pengaruh Jumlah Uang Beredar (M2) Terhadap DPK Bank Syariah.

Variabel Dana Pihak Ketiga (DPK) bank syariah merespon negatif guncangan variabel M2 pada jangka panjang. Artinya, dalam jangka panjang terdapat hubungan yang negatif dan signifikan antara variabel DPK dan jumlah vang beredar (M2). Hal ini selaras dengan 
Adim, et al/Jurnal Ekonomi Syariah Teori dan Terapan Vol. 4 No. 8 Agustus 2017: 642-656; Pengaruh Guncangan Kebijakan Moneter dan Variabel Makro Terhadap Dana Pihak Ketiga (DPK) Bank Syairah di Indonesia

penelitian oleh Haron dan Azmi (2008). Haron dan Azmi (2008) menjelaskan bahwa peningkatan pada jumlah vang beredar akan membuat suku bunga kredit bank konvensional akan mengalami penurunan, sehingga membuat biaya pinjaman oleh para peminjam lebih murah. Hal ini membuat masyarakat akan meminjam vang lebih banyak dari bank untuk kebutuhan konsumsi dan menurunkan tabungan. Sehingga dapat disimpulkan bahwa dalam jangka panjang ketika jumlah vang beredar di masyarakat meningkat maka dana pihak ketiga bank syariah akan menurun.

Sedangkan dalam jangka pendek terdapat hubungan yang positif tetapi tidak signifikan antara DPK dan M2. Hal ini selaras dengan penelitian yang dilakukan oleh Paul Oejega dan Deborah (2014). Paul Oejega dan Deborah (2014) ini juga menjelaskan bahwa dalam jangka pendek peningkatan jumlah vang beredar (M2) ini akan digunakan masyarkat untuk konsumsi dan saving. Akan tetapi, porsi konsumsi lebih besar daripada porsi untuk saving, sehingga hal ini berpengaruh tidak signifkan terhadap DPK bank syariah.

4. Pengaruh Indeks Harga Konsumen (IHK) Terhadap DPK Bank Syariah

Hubungan Dana Pihak Ketiga (DPK) bank syariah dan Indeks Harga Konsumen (IHK) ini sama halnya dengan hubungan antara DPK dan BI Rate yaitu baik dalam jangka panjang maupun jangka pendek, DPK bank syariah merespon negatif guncangan variabel IHK. Artinya terdapat hubungan negatif antara DPK dan IHK. Hal ini selaras dengan penelitian yang dilakukan oleh Muhammad Abduh et al. (2011), Sahliyah (2015),Siaw dan Peter (2015), dan Haron dan Azmi (2008). Siaw dan Peter (2015) menjelaskan bahwa, ketika perekonomian pada kondisi inflasi yang tinggi, maka pelaku ekonomi, baik itu rumah tangga maupun perusahaan akan dipaksa untuk melengkapi pengeluaran mereka untuk membeli barang untuk produksi dengan cara meminjam vang pada bank, sehingga akan mengurangi deposito perbankan.

Muhammad Abduh et al. (2011) menjelaskan bahwa ketika terjadi inflasi yang tercermin dari tingginya harga barang dan jasa yang dikonsumsi masyarakat, sehingga membuat masyrakat terpaksa mengeluarkan lebih banyak dana atau vang mereka untuk kebutuhan konsumsi, sehingga secara tidak langsung mengurangi pendapatan masyarakat dan mengurangi kemampuan masyarakat untuk menabung di bank syariah. Akhirnya, Dana Pihak Ketiga (DPK) bank syariah akan mengalmi penurunan.

\section{v. SIMPULAN}

Berdasarkan hasil analisis dan uji hipotesis yang telah dilakukan dalam penelitian ini, maka simpulannya sebagai berikut:

1. Terdapat hubungan positif antara Dana Pihak Ketiga (DPK) bank syariah dengan Produk Domestik Bruto (PDB), baik dalam jangka penjang maupun jangka pendek. 
2. Baik dalam jangka panjang maupun jangka pendek, variabel BI Rateberpengaruh negaitf terhadap Dana Pihak Ketiga (DPK) bank syariah.

3. Dalam jangka panjang, terdapat hubungan negatif antara DPK bank syariah dan jumlah vang beredar (M2). Sedangkan dalam jangka pendek, terdapat hubungan positif tetapi tidak signifikan antara DPK dan jumlah vang beredar (M2).

4. Variabel Indeks Harga Konsumen(IHK) berpengaruh negatif dan signifkan terhadap dana Piahk Ketiga (DPK) bank Syariah baik dalam jangka panjang maupun dalam jangka pendek.

Berdasarkan langkah-langkah yang telah dilakukan dalam penelitian ini sampai penelitian ini selesai, maka saran untuk penelitian selanjutnya terkait topik dan tema yang sama sebagai berikut:

1. Bagi peneliti selanjutnya dapat menambahkan variabel penelitian lain yang mempengaruhi DPK bank syariah, seperti: Jumlah kantor cabang, dll.

2. Peneliti selanjutnya juga dapat menambah periode waktu penelitian agar penelitian lebih akurat

3. Dapat menambahkan variabel makroekonomi yang dapat berpengaruh terdapat DPK, seperti nilai tukar, krisis, dll.

\section{DAFTAR PUSTAKA}

Abduh, Muhammad dan Raditya Sukmana. 2012. Deposits Behavior In Indonesia Islamic Banking: Do Crisis or Fatwa Matter? IIUM. Malaysia

Affandi, Ahmad dan Luayan Tamanni. 2010. Monetary Policy Shocks and Islamic Banks Deposits in Dual Banking System After The Financial Crisis. Jurnal Keuangan dan Perbankan, Vol. 14, No. 3

Ascarya. 2006. Akad dan Produk Bank Syariah: Konsep dan Praktek di Beberapa Negara. Jakarta: Bank Indonesia.

Badan Pusat Statistik. 2015. Indikator Perekonomian : Produk Domestik Bruto (PDB) 2016. www.bps.go.id diakses pada tanggal 5 Juli 2016 pukul 19.00 WIB.

Cetin, Huseyin. 2014. Econometric Modelling of Turkish Participatory Banks Deposits. International Kournalof Trade, Economicsand Finance, Vol. 5, No. 4.

Hakan, Ergec dan Arslan Bengul Gulumser. 2011. Impact of Interest Rates on Islamic and conventional Banks: The Case of Turkey. Munich Personal RePEC Arcihve, 1-2.

Haron, Sudin and Wan Nursofiza Wan Azmi. 2008. Determinantsof Islamic and Conventional Deposits in the Malaysian Banking System. Journal Managerial Finance Vol. 34, No. 9. Malaysia

Huda, M. H. 2010. Lembaga Kuangan Islam : Tinjauan Teoritis dan Praktis. Predana Media Grup. Jakarta.

Kasim, S., Abdul Majid, M.S. and Mohd Yusof, R. (2009). Impact of monetary policy shocks on the conventional and Islamic banks in a dual banking system: evidence from Malaysia, Journal of Economic Cooperation and Development, Vol. 30 No. 1

Kasri, R. A. dan Kassim, S. Hj. (2009) Empirical determinants of saving in the Islamic bank: evidence from Indonesia, journal of king Abdulaziz University: Islamic Economic, 22, 181-201

Mankiw, N. Gregory. 2003. Pengantar Ekonomi Makro. Edisi 3. Terjemahan oleh Chriswan Sungkono. Jakarta: Salemba Empat.

Manurung, Mandala dan Pratama Rahardja. 2004. Uang, Perbankan, dan Ekonomi Moneter (Kajian Kontekstual 
Indonesia). Lembaga Penerbit FE.UI. Jakarta

Mohammad Abduh, dkk. 2011. The Impact of Crisis and Macroeconomic Variables towards Islamic Banking Deposits. American Journal of Applied Sciences 8(12): 1413-1418, 5-6.

Muhammad. 2002. Manejemen Bank Syariah. Yogyakarta: Unit Penerbit dan Percetakan (UPP) AMPYKPN.

Nwachukwu, Tochukwu. E. and Festus. O. Egwaikhide. 2007. An Error-Correction Model of the Determinants of Private Saving in Nigeria. A Paper presented at the African Economic Society (AES) Conference, Cape. Nigeria

Ojaega, Paul and Deborah Odejimi. 2014. The Impact of Interest Rates On Bank Deposits Evidence From The Nigerian Banking Sector and Regional Overview. International JournalofArts dan Science. University of West Sweden.

Otoritas Jasa Keuangan. 2015. Statistik Perbankan Syariah Desember 2005 sampai dengan Desember 2015. www.ojk.go.id

Sahliyah, F. 2015. Pengaruh Faktor-Faktor Ekonomi Makro Terhadap DPK pada Perbankan Syariah di Indonesia, Periode 2006-2013. Thesis. Surabaya: Tidak Diterbitkan;Universitas Airlangga.

Siaw, OtuLarbi and Peter Augmor Lawer. 2015. Determinants of Bank Deposits In Ghana: A Cointegration Approach. Asian Journal of Economics and Empirical Research, Vol. 2, No. 1

Sukmana, R. and Kasim, S. 2010. Roles of the Islamic banks in the monetary transmission process in Malaysia. International Journal of Islamic and Middle Eastern Finance and Management, Vol. 3 No. 1, h. 7-19.

Yusof, R. M. 2008. Monetary Policy Shocks and Islamic Bank's Deposits In a Dual Banking System: a Comparative Analysis Between Malaysia and Bahrain. 8th Globar Conference on Business and Economics, 10-12.

Yusoff, Remali and Rodney Wilson. 2005. An Econometric Analysis of Conventional and Islamic Bank Deposits In Malaysia. Journal Riview of Islamic Economics, Vol. 9 No. 1 